The International Journal of Human Resource Management, Volume 23, Issue 16, 2012, Pages 3434-3454

Measuring the return on investment in international assignments: an action research approach 


\section{Measuring the return on investment in international assignments: an action}

\section{research approach}

This paper progresses the debate on the underresearched topic of return on investment (ROI) in international assignments by complementing and extending recent research streams on the conceptual understanding and challenging nature of measuring ROI. The study reported in this paper applies an action research methodology. Working in close collaboration with nine multinational companies, a set of metrics were developed to explore and gauge the ROI of international assignments. An in-depth exploration of the assignment purpose and individual and organizational otucomes over time highlights the importance of context and the dynamic nature of the task of assessing ROI. These themes have significant implications for international assignment strategy policy and practice. Insights from an action research perspective are discussed.

Keywords: Return on investment, international assignments, expatriation, action research 


\section{Introduction}

Two recent publications in the International Journal of Human Resource Management have taken up the challenge of addressing the measurement of return on investment (ROI) in international assignments (IAs). Echoing the enduring issues around measurement and how human resource management (HRM) impacts the bottom line (Ulrich 1997a,b) these papers make two major contributions to a sparsely researched field. One, they highlight conceptual issues which fundamentally influence the nature of any formal measurement systems and two, they raise the issue of the Human Resource Management (HRM) function's ability and influence in the development and application of measures of ROI.

Based on their two-country study of nine multinational companies which polled both organizational representatives and repatriates, Welch, Steen and Tahvanainen (2009) using an interpretive perspective, explore HR managers' and expatriates' experiences of the practices and activities of international assignments. They argue that companies do not have formal systems in place because ROI may be an inappropriate approach to measuring human asset investment rather than an inability of HR managers to calculate ROI. They suggest that individuals are more attuned to their personal and professional development and are not necessarily concerned with any return for the employing firm. Coupled with the lack of formal systems of measurement and a continuing trend for many of the HR activities associated with expatriation such as re-location and compensation being outsourced to external providers the authors suggest that the role of HR may be eroded and that there may be negative connotations for the perceived value of IAs.

From their qualitative data, Welch et al. (2009) argue that intellectual capital may be a potentially more relevant construct to apply in assessing IA outcomes, as it 
facilitates the capture of interdependent, long-term and intangible costs and benefits such as those associated with knowledge transfer, the introduction of new processes and routines, and networking. The use of the intellectual capital construct may facilitate the inclusion of the role of individual agency in career development in the international assignment situation. This is particularly relevant as there are currently few employment or career progression guarantees for expatriates, even though they have been traditionally highly sought-after populations. Many organizations have been reporting difficulties in sourcing and engaging suitable people to undertake an IA and this is an issue recognized both in academic writing as well as in trend surveys (Scullion and Starkey 2000; GMAC 2006; Collings, Scullion and Morley 2007). Given that there is some debate that the ROI of IAs is not just company focussed but that individuals are keen to develop their career capital maybe even at the expense of their employing organization (Dickmann and Doherty, 2010), it has become increasingly important to pay attention to the subjective career needs of individuals (Ng, Eby, Sorensen and Feldman 2005). In particular it is essential to understand the changing ambitions of expatriates, to address the need to make the expatriation experience an attractive opportunity (Hippler, 2009).

There is a need to understand more fully the individual motivation to undertake IAs as significant correlations between the factors considered highly influential to the decision to undertake an assignment and the perceived benefits in terms of career capital have previously been established (Dickmann, Doherty, Mills and Brewster 2008). In particular where there is a perception that job and leadership skills development are highly influential to the decision to go, individuals indicate a positive impact on their know-how, on their motivation, their internal promotion and their perceived external employability. 
Such research signals a potential discord between organizational and individual goals in expatriation which may explain some of the recently highlighted paradoxes of international working where the anticipated benefits for individuals and organizations often remain unmet (Doherty and Dickmann 2009; Dickmann and Doherty 2010). There are potentially disparate goals for expatriation between individuals and organizations, therefore distinguishing the perspective, whether individual or organizational, is fundamental to the assessment of ROI. The individual perspective may focus on longer-term, career-oriented outcomes while organizational goals may be shorter-term, business-needs driven. Assessing such disparate outcomes require different measurement approaches and metrics. This presents challenges in firstly determining the goals of IAs and secondly in designing appropriate measures. The metrics used need to facilitate data gathering and interpretation to align with the individual or organizational perspective and the proposed goals. Such alignment is essential to any effective and helpful assessment of ROI for both individuals and organizations. However, due to the intangible nature of many of the outcomes of expatriation, definition and measurement remain difficult both at the individual and organizational levels. Although Welch et al. (2009) convincingly argue for the inclusion of intellectual capital in the measurement of ROI, they acknowledge that the theoretical complexity of the intellectual capital concept itself poses methodological challenges in developing reliable and valid tools.

The second paper to make a major contribution to the ROI debate, by McNulty, De Cieri and Hutchings (2009) highlights the limited work which has attended to ROI, even though international assignments continue to be an important strategic tool in the global context. They suggest that "ROI remains a challenging and complex process that managers in global firms are not well equipped to address" (p. 
1309). In their survey of global firms, McNulty et al. explore ROI from a management perspective using a HR systems approach. Defining ROI as a comparison of the financial and non-financial costs and benefits relative to the assignment purpose (following McNulty and Tharenou 2004) they examine how ROI is measured, barriers to measurement and variables influencing changes to the ROI of long-term assignments. Significantly, none of the 51 global firms in their sample formally measure ROI. In fact, some managers consider expatriate ROI as unnecessary or inappropriate. Where measures are in place, most commonly, these are informal such as a short-term functional assessment of the immediate benefits assessed in terms of the local objectives of the role, for example local successor groomed. Others informal measures include repatriation numbers, turnover and premature returns or failures.

In the McNulty et al. study, when explaining the lack of ROI measures some managers quote obstacles such as cultural barriers (lack of buy-in or the perception that expatriate cost is a fundamental part of the cost of doing business); operational barriers (lack of functionality in software or issues connected with the structure of the mobility programme) and strategic barriers (lack of planning evident in the inability to develop ROI measures and lack of accountability / ownership). None of the respondents indicate that they have been able to develop a measure for ROI.

The availability of appropriate data, due to time, resource, and strategic support constraints or lack of appropriate software, appears to be a major stumbling block. The authors propose that three main areas of focus are relevant to measuring ROI. In the broader context they suggest the need to appreciate structure, culture and the changing nature of expatriate assignments. Within the organizational context, measuring ROI requires a clear definition of what return means relative to the 
organization's mobility programme. In addition, there is a need to identify and understand the independent and interdependent nature of the variables that influence rates of return within the particular organizational context. These are tasks that companies appear reluctant or unable to achieve (McNulty et al. 2009).

Given the apparent complexity of measuring ROI in international assignments this paper examines the factors impacting the measurement of ROI and explores how organizations attempt to assess ROI. It reports on the development of a range of metrics and a process, using an action research approach. The paper analyses the purpose of expatriation, investment, performance, promotion and repatriation and retention as the key foci of measurement. It considers the applicability of an action research approach in future research.

\section{The 'holy grail' of international mobility}

Measuring the ROI of global assignments is a complex undertaking, one sometimes likened to unearthing the 'holy grail' of international mobility. The two papers reviewed above provide empirical support for the critiques levelled at research on ROI and a number of issues have been highlighted. The literature on expatriation initially lacked a sound theoretical foundation, studying the different elements of expatriation independently (Bonache, Brewster and Suutari 2001). The epistemological basis for research on expatriation has been extended to draw on a considerable range of theories from other fields. In a recent special issue of 'CrossCultural Management' authors used institutional theory (Ando 2011); psychological contract theory (Tornikoski 2011), role theory (Kittler, Rygl, Mackinnon and Wiedemann 2011), cultural studies and psychology (Cole and McNulty 2011) to explore expatriation. In the general literature, many authors write from the individual 
perspective and many from the organizational perspective, including theoretical lenses from individual and organizational psychology, career development, and HRM, but few provide a cohesive or coherent frame of reference to unite these perspectives for the purposes of research and practice. Although various sources point out that the costs of a long-term ( $>1 \mathrm{yr}$ ) international assignment are high (Dowling, Festing and Engle 2008, pp. 159-175), ROI is poorly calculated, not widely used (Cendant 2002) and not widely researched (McNulty et al. 2009; Welch et al. 2009).

It is important to acknowledge that there has been an enduring issue around measurement and the ability to show the contribution of HRM to the bottom line (Ulrich, 1997a,b). For the case of IA, similar measurement issues persist. Thus, few organisations have yet developed mechanisms to track the ROI of an international assignment, providing little information on which to base ROI considerations (Brookfield, 2010). There is a lack of consensus on what ROI from expatriation should be (Black, Gregersen, Mendenhall and Stroh, 1999) and little tracking of career outcomes for repatriates (Lazarova and Cerdin, 2010; Collings, Doherty, Luethy and Osborne, 2011). Often, organizations focus on the 'hard' costs as these are easier to measure. These include base salary, foreign service inducement/hardship premiums, allowances and benefits (Dowling et al. 2008, pp. 162-164) including special vacations and leave, travel expenses and costs in preparing the individual to work abroad (Dickmann and Debner, 2011, pp. 273-280). Other hard costs such as administrative support for expatriates provided inside the organisation (predominantly outsourced) and taxation and other advice may also be included. Less tangible costs within the home organization include replacement and on-boarding costs. At the host location, costs may also be represented by the reaction of locals, including the issue of legitimacy, the potential perception of career ceilings, and the impact on host country 
relations and reputation (Hailey and Harry, 2008). Knowledge creation, transfer and exploitation issues (Hocking, Brown and Harzing 2004) both in the host as well as sending units and the impact on morale are further outcomes that are very difficult to assess in an ROI calculation. Moreover, assessing the (opportunity) costs/benefits of expatriate performance, potential or career/leadership opportunities present a highly challenging task. Costs and benefits associated with the expatriate, including individual and family adjustment, dual career concerns and children's schooling, health (Haslberger 2005, 2008) are factors not normally assessed by organizations.

The many non-financial outcomes to the use of expatriation include cultural and knowledge transfer. However, there has been limited attention to the performance of expatriates (Harrison and Schaffer 2005) with little focus on the dimensions of performance (Thomas and Lazarova, 2006). The focus of work has been on expatriate adjustment and early return. While these areas are important, it is also necessary to evaluate the benefits of international mobility to careers, to expatriate retention and to performance over time. Much research has taken a static rather than a dynamic perspective and the need to explore the temporal element is supported by McNulty and Tharenou (2004), who suggest a long-term perspective in expatriation. In terms of the assessment of any return on investment in expatriation, McNulty et al. (2009) claim that ROI needs to be measured at different times, depending on the various purposes of the assignments as the purpose of the assignment dictates both what is included in the ROI calculation and the most appropriate time frame for the calculation (Bonache et al. 2001), since assessments made over different time intervals can reveal different outcomes. For instance, if the primary purpose of expatriation is skill gap filling then a 'return on investment' for the organization is likely to accrue predominantly during the time of assignment (Kraimer, Shaffer and 
Bolino 2009). In contrast, if the organization aims to develop the individual into a global leader of the future, the 'return on investment' is likely to accrue over a longer time period with much of the 'pay back' potentially happening after the assignment (Stahl et al. 2009). In this scenario, the individual may also have a larger stake in the outcomes of the international work as these are likely to be interwoven with their own careers. Where assignments are predominantly used for control and co-ordination purposes, individuals, organizations and wider societal effects embodied in knowledge transfer unfold over time. Knowledge transfer starts with the international assignment and continues over a long-term time period after the expatriate assignment has ended (Dickmann and Baruch, 2011, pp. 222-240). Thus, there is a need for measures of expatriate ROI to be time-sensitive and to employ a variety of perspectives.

The practices applied by organizations in the management of international mobility are often temporally framed, as the IA is frequently split into "before", "during" and "after" phases. An example for this is the global assignment cycle (Sparrow et al. 2004, p. 145). In the pre-departure phase organizational policy and practice focus on planning the assignment, selecting the individual, administering the relocation programme and conducting preparatory training and development. In the assignment phase policy and practice address compensation, family support, performance management and preparation for repatriation or for re-assignment. In the post-assignment phase retention of the individual is the focus. Ideally, this would include renewed efforts to re-integrate returning international assignees into organizational career systems to further their career progression without the potential for career disruption or 'wobble’ (Doherty and Dickmann 2007, p. 8). 
Part of the problem in achieving coherent tracking of outcomes, reflected specifically in the expatriation case, may be due to issues in the management of talent in general as evidenced by Lewis and Heckman (2006) in their critical review of the literature. They suggest that there appears to be a disjointed and incoherent approach to the management of talent. Research to date does not discriminate between methods of managing talent and an analysis of the need for selective or general talent development. This close coupling of content and process within a global context raises issues for the management of expatriation as part of the talent flow in an organization. The management of talent which is developed through international exposure has generated various prescriptive approaches to developing people in the global context (e.g. McCaughey and Bruning 2005; Bonache and Zárraga-Oberty 2007). Collings et al. (2007) suggest that for international assignments the challenge for IHRM is to ensure that there is clarity in the goals of the assignment. This focus, they argue, is necessary for the measurement of the utility and contribution of expatriate assignments. The task for HR practitioners is the development and use of congruent HR policies (p. 210) which will facilitate successful completion of an assignment and repatriation into the home organisation to engender a willingness among employees to go on assignment.

Overall, many of these challenges have meant that the academic literature has focused on the lack of cohesion and the deficiencies in the field of research on ROI. Lack of advances in the ROI literature appears to stem from limited progress in the practice of measuring ROI. Since few companies appear to have developed or use measures of ROI in expatriation, academic debate has focused on the lack of research in this field as there is little to report in terms of practice. Approaching ROI in a more integrated way to capture data which link the organizational impetus for expatriation 
and the individual experience of expatriation may help to break this circle. Such integration of the individual and organizational levels may help to bridge the gap between the development of human capital which encompasses the skills, knowledge, abilities and capability of employees to learn (Stiles and Kulvisaechana 2003) and the individual level career capital which employees bring to, develop in and take with them when they leave an organisation (Inkson and Arthur 2001; Inkson and Clark, 2010).

Such integration would help make more explicit the links between international assignments and outcomes (Dickmann and Doherty 2010). In order to clarify the link between individual and organizational level it is important to consider the financial investment made by the organization in employing and developing expatriates, the performance of expatriates in their role, their promotion relative to their individual career trajectory and repatriation and retention as part of the talent pipeline and contribution to the organizational reservoir of skills, knowledge and abilities.

\section{A methodological challenge}

Adopting an HR systems approach (McNulty et al. 2009) or an alternative take on the capital acquired from international assignments (Welch et al., 2009) indicate the tension between assessing the individual and organizational levels of outcomes. This has led to few companies attempting to measure the ROI on international assignments. Addressing the range of issues highlighted by and limiting previous research, poses a challenge methodologically. The current paper develops the thesis that an alternative approach to researching the issue may shed some light on the ROI enigma and argues that an alternative methodology is timely. Rousseau and Fried 
(2001) proposed the more widespread use of contextualization, due to the increasing internationalization of organizational research and the rapidly diversifying nature of employee-organizational relations. They highlight the need to be aware of how the level of contextualization impacts on the design, assessment, implementation and interpretation of research. Achieving contextualization requires a rich description of the setting, establishing frames of reference and the inclusion of a temporal dimension ie. tracking the outcomes of expatriation over time. In support of the need for contextualized data, Cappellen and Janssens (2005) suggest that although there is currently a great deal more fluidity in firm boundaries, the context remains important (p. 356) in the study of the career development of global managers, which is one important aspect of the ROI on IAs. Methodologically contextualization implies an understanding of the organizational context which is facilitated by a case study approach; however, such an approach needs to include the measurement of outcomes over time, incorporating the calculation of the financial and non-financial costs to provide a useful assessment of ROI.

In addition to the importance of context, the difficulty in generating measurement techniques which can adequately address the analysis of ROI has been attributed, at least in part, to a lack of skills among organizational HR representatives. We suggest that this signals the need to develop metrics that are feasible and suitable for purpose for practitioners. In line with the themes highlighted by Welch et al. (2009) and McNulty et al. (2009) the research reported in this paper was guided by a number of principles. First, ROI is linked to the diverse purposes of expatriation. Second, the ROI on international work is relative to the context of the organization and the promotion or retention (or other meaningful comparators) of non-expatriated peers. Third, an assessment of ROI needs to evaluate both costs and benefits. Significantly, the research contributing to this paper takes an action research approach in order to overcome the 
issues of buy-in, the challenge of the dynamic nature of ROI and the important impact of contextual factors on measurement. Therefore, this paper sets out to move closer to a contextualized understanding of, and method appropriate to, the measurement of ROI for IA (Dickmann, Doherty and Johnson 2006).

\section{With practitioners, by practitioners, for practitioners}

The methodology adopted here is based on the premise rehearsed by Hodgkinson and Rousseau (2009). They argue that where research is informed by practice, through engagement with practitioners either as partners or collaborators in the research process then different outcomes result, compared to a more academic approach to research. For example different variables are often investigated yielding information and knowledge distinct to that produced by research driven purely by academic enquiry. Hodgkinson and Rousseau argue for the generation of actionable knowledge which is both shaped by and shapes the dynamics of the systems through which knowing is accomplished. It is also suggested that such actionable knowledge is of substance practically, since it tends to use metrics which are of value and of intrinsic interest to practitioners, in this case for example measures of expatriate performance and retention. Hence, the knowledge produced is more likely to change practice. An action research approach in the British tradition, as a collaborative, self-reflective exercise designed to directly enhance practice (Carr and Kemmis 1986), offers a practical way forward. Our approach involves engagement with practitioners to develop critical reflections, in this case, on the approach to ROI, to enable the development of workable, appropriate and applicable processes and tools. Thus, while previous research on ROI has tended to be driven by an academic impetus and agenda, the research reported here adopts a process of active engagement with 
practitioners. This extends and adds understanding to the knowledge base on the practise and processes which add practical value to the calculation of ROI. Moving beyond an exploration of the issues as done in previous research (McNulty et al. 2009; Welch et al. 2009) our approach actively worked with practitioners to develop and produce a process and metrics which they were facilitated to apply within their organizational contexts.

\section{The data collection process}

In the first step of the research, discussions were held with a Steering Committee, comprising representatives of 15 multi-national organisations, Cranfield School of Management and PwC Saratoga. These discussions reflected a strong desire to have a metrics-based approach, illustrative of the increasing pressure on companies to justify their investment decisions (Pfeffer and Sutton 2006; Strack, Caye, Thurner and Haen 2009) through the use of evidence based management. The steering committee contributed to the formulation of the aims of the research.

The mode of engagement for companies involved a high degree of cooperation with the research team. A series of meetings and interviews formed the basis of discussion about the research and details of the data required. PwC Saratoga developed a series of metrics and provided a key person to assist all nine companies to address queries about the measures and the process. A minimum of two and a maximum of three meetings were held with company representatives (normally the director of international mobility and/or other IA specialists), two representatives from PwC Saratoga and one of the academic researchers. The same Saratoga professional and one of the authors visited the companies to explain the measures, answer queries and facilitate the data collection process. 
The sample was selective. Only those companies which recognized and agreed to the methodological approach being applied and which were able to actively participate in the research process are included in the analysis (Table 1). Nine organizations participated in the data collection and interpretation phase of the research. These companies reflected a perceived alliance with and desire for a supported effort in developing and interpreting measures of ROI. Organizational representatives were of the view that not only would a metrics-based approach allow them to develop a more coherent view of their own internal processes and practices with regard to ROI in IA but it would also allow them to make cautious crosscompany comparisons relative to other participating companies, providing valuable input into global mobility decisions as suggested by trend data. This reciprocal approach held considerable face validity for those firms which signed up to the process.

\section{INSERT TABLE 1 ABOUT HERE}

The research team, in collaboration with the case companies, applied a series of metrics anchored by organizational needs but also guided by practical expertise and knowledge of the formulae (the calculations required for the metrics) necessary for defining meaningful measures. The measures were based on precise definitions to facilitate a comparative positioning with other organizations. Assessments were as highly standardized as possible. Some organizational representatives were concerned that the required data would not be easily available or would entail collation from several different systems and sources. However, over the course of the research phase, research meetings with key organizational representatives facilitated the collection and collation of appropriate data of the quality, completeness and accuracy needed. 
Above we have outlined a large range of possible costs and benefits in expatriation. The choice of measures was principally guided by the following considerations. First, the metrics had to assess both costs and benefits. Second, it was necessary to ensure that the metrics developed could be incorporated into the IT systems of the case companies as they intended to use these in the future. Third, data required for calculation of the metrics needed to be reasonably easily available to participating organization. Fourth, the validity and perceived usefulness of the data was important. These pragmatic considerations made assessing the less tangible costs (such as on-boarding or knowledge transfer) inappropriate.

Since no case company had measures beyond basic costs in place this research facilitated an organizational advance in ROI measurement. For example, expatriate investment is one key metric calculated. This consists of expatriate remuneration (total compensation + long-term benefits + expat allowances) and expatriate management costs, expatriation related learning \& development costs and other outsourced costs (see Appendix A). The high degree of access enabled the collection of sensitive information such as specific remuneration data for expatriates. Due to the complexity and dynamism of assessing their valuation, stock options were not included in the expatriate investment assessment.

Retention, performance and career progression are key metrics which organizations can more easily collate (Sparrow 2006) and which address both individual career concerns and organizational needs. The present study was guided by the premise that with respect to retention, turnover becomes a more meaningful metric when a non-expatriated, matched peer group is used as a comparator. In contrast to most prior research which used subsets of expatriated personnel, this study collected data on all international assignees in the nine case companies. 
Performance management and appraisal data for expatriated and nonexpatriated staff were compared. This provided an index of the effectiveness of working in an international environment particularly where expatriates had local objectives. All companies had an internationally integrated appraisal system. We used relative ratings over time to assess performance trends when working abroad and upon the first three years after return.

Promotion paths and progression for international assignees were compared to non-expatriated individuals. The promotion of expatriates is a signal of the potential attractiveness of IAs as a career move and as a succession planning mechanism, symbolic of the importance of IA within the organizational context (Doherty and Dickmann 2009).

Taking stock of the individual level data regarding performance improvements, career moves, plateauing or decline as well as promotion provides valuable data with respect to the outcomes of IAs. Through the continuous process of data collection and discussion with organizational representatives, measurement issues were resolved within individual organizational contexts and suitable indices developed. The research goes beyond the traditional boundaries of focusing on current expatriates, by assessing what has happened with assignees whose IA ended up to three years previously. This builds a cumulative picture of the retention and promotion trends for repatriated individuals.

A range of contextual data was gathered to assess the applicability of metrics in different company and industry environments. In addition, participating companies provided relevant internal documents that facilitated an in-depth exploration of each company context. The combination of interviews, meetings and formal documentation provided data on the international mobility strategy, assignment purposes, 
international investment data, career, individual development, performance and retention data over time. Crucially, the data allowed a comparison of expatriates and repatriates with non-expatriated peers to gain an insight into the meaning of compensation, promotion, retention and performance data. Other specific criteria required for participation included a commitment from the organisation to provide the data required within a specified timeframe (approximately 2 months) and the ability to identify a base "reporting period". This was a period of 12 months, for which easily extracted data were available for analysis and which provided contextual data against which comparisons could be made internally over time and across companies. The data were collected between June and September 2006 with a reporting period referring to 2005 .

In order to respect the confidentiality of the participants, organizations will not be identified rather collated data are presented and discussed. Those organisations taking part in the research were headquartered in the United States, UK and continental Europe. The combined headcount of these companies was in excess of 500,000 employees. An 'expatriate' was defined as an employee who is not locally employed by the host location, but who is transferred by the organisation and covered by a company relocation policy, i.e. is 'sent out from a home to a host country'. Participating companies had varying degrees of international assignment management experience, from those with historically established global assignment policies and practices, to those with recently established programmes of international working. In absolute terms the number of expatriates was 3,450 for the nine organizations.

Although the benefits of international assignments are more difficult to evaluate, as highlighted by McNulty and Tharenou (2004), the level of access to the nine case companies facilitated by the action research approach meant that data 
regarding both expatriates and non-expatriated peers could be collected. These data were in a less standardized format, gained through discussions and consultation with organizational experts. While this renders the data less comparable across companies, this information provided a good indication of whether the expatriate promotion or retention rates were higher or lower than for their non-expatriated peers within individual companies. These data were interpreted in collaboration with company professionals to determine whether they indicated positive trends or uncovered particular issues with respect to the development of the expatriate cadre. This facilitated a view on the relative benefits of international assignments. Examples of company initiatives originating from the insights developed through this action research approach are outlined towards the end of this manuscript.

The next sections outline the key findings of this research approach, rehearsing the issues faced by organizations and the challenges of managing expatriate populations within the current global context. The results of this study are reported under the five main banners of: purpose of expatriation; investment; performance; promotion; and repatriation and retention.

\section{The purpose of expatriation}

Perhaps not surprisingly for the types of organization engaging in this study, the international mobility policies indicated a range of stated purposes for global working. These included achieving and sustaining a global presence, providing an opportunity for cultural exposure, and facilitating an enhancing life experience and deeper understanding of alternative organizational contexts. Overall, most of the participating organizations reported an increase in the number of expatriates, over the period of the study. This was evidenced in an upward trend with nine percent more expatriates 
being sent out on assignment in the reporting period than those returning from assignment.

In line with work that differentiates the purpose of different types of IAs (Edström and Galbraith 1977; Bonache and Brewster 2001; Dickmann et al. 2008) all case companies were asked to distinguish between assignments instigated by shortterm business drivers (including skills shortage and rapid deployment), long-term business drivers (including control, corporate culture coordination, knowledge and technology transfer) and developmental drivers (including career development and global leadership aims).

One corporation indicated that the assignments were predominantly driven by short-term business needs including filling skills shortages. Two firms signalled key developmental business needs such as career and global leadership development for the future leadership of the company. While the enhancement of individual professional growth was a fundamental underpinning purpose, by far the largest number of organizations (seven) indicated that the primary assignment purpose was to fulfil long-term business needs such as knowledge transfer and control and coordination. There was a growing trend for the knowledge transfer impetus as more expatriates were sent out in the reporting period for this purpose than those who were ending their assignment. Overall, assignments were fundamentally business driven. The second most important reported goal of IAs was to enhance individual professional development. Sixteen percent of all expatriates were identified as members of the company's talent pool. Eighteen percent had their own personal and professional development as a primary goal, defined as a pre-departure objective (see Table 1). 
These data corroborate trends outlined by organizations such as GMAC (2008), ORC (2008) and ECA (2010). The individual's assignment objectives were explicitly linked to performance appraisals in eight of the nine case companies, highlighting the importance of gathering performance data for assignees. Two companies indicated that global leadership and developmental considerations were paramount, however this was a less important driver for the other companies. The importance attributed to development suggests that retention figures and promotion data over time can serve as a rough indication of the benefits of global work in relation to the corporations' aims and investment in IA, an issue we now turn to.

\section{Investment}

The direct compensation costs of the assignment, outsourcing investments and the cost to the organization of managing the IA programme were the key metrics used to assess the overall costs associated with the management of expatriates (see Table 1 and Appendix A). For the majority of the case companies the international relocation policy adopts a balance sheet method of determining compensation, where the individual is paid on the basis that their net compensation should leave them in a position where they are no better or no worse off than had they stayed at home. However, two of the case organizations use a destination pay approach to compensation and one organization uses a mix of expatriate compensation policies, typically dependent upon regional norms. The benefits, risks and administration efforts required by different remuneration methods has been outlined elsewhere (Dowling et al. 2008; Dickmann and Debner 2010). 
The expatriate investment (outlined in Table 2) averaged $£ 171,022$ per expatriate, per annum. Average salary was $£ 104,676$, with assignment allowances averaging $£ 54,049$. Expatriate management costs per assignee were on average $£ 12,309$. There are estimates in the literature suggesting that the costs of expatriate staff can be between three and in exceptional cases (depending on the location) up to ten times as much as a domestic employee (Harris, Brewster and Sparrow 2003). Interviews with the HR professionals in our diverse sample of organizations indicated an estimated 'premium' of between $40-110 \%$. Data provided by Saratoga for average managerial remuneration across Europe and USA (the origins of our participating companies) indicated that the expatriate assignee in our research costs the organization $68 \%$ more than managers working domestically. This suggests that our sample of firms had lower 'expatriate premiums'. The substantial difference between previous estimates and the current findings may reflect a trend in the reduction of the size of expatriation premiums (GMAC 2008; Dickmann and Baruch 2011). We acknowledge that there are some high cost locations, some sectorally and geographically specific, which may account for spikes in expatriate premiums due to high salary levels or costs relating to security issues, however the methodology and assessment of the costs of all expatriates in the participating corporations provides an inclusive picture.

We concentrated on the direct costs associated with expatriate moves, factoring in training and development investments and the salaries of international mobility staff. There are, of course, costs such as opportunity costs (including benefits) of moving a person (and her/his family) to another job and country. There is very little known regarding the opportunity costs of foreign moves and while this 
merits further exploratory study, the current research did not assess opportunity costs. The higher costs of international assignees vis-à-vis their non-expatriated peers, points to the need to assess the benefits associated with their expatriation experience. One key benefit is the potential performance improvements gained, an area which we consider next.

\section{Performance}

Metrics were developed which allowed companies to gauge relative changes in expatriate performance over time. The existing performance appraisal systems, none of which had been changed in the two years before the reporting period deadline were used in each of the nine case companies. Across all 3450 expatriates, performance ratings had improved for $28 \%$ and decreased for $15 \%$ compared to their preassignment evaluations (see Table 1). These data indicate that performance can improve and can also decline while on assignment. The net improvement was also reflected in the performance appraisal outcomes of repatriates. Those who had returned from assignment had a six percent net improvement in their ratings in the first year after return (see Table 1). Notably, this trend continued during the three years after their return with net improvements ranging from seven to twelve percent among repatriates. Overall the data indicate a positive performance trend, although there was some variation in performance on repatriation.

Many sources of bias and unintended outcomes of performance appraisal are possible (Beardwell and Claydon 2007), and Marchington and Wilkinson (2007, pp. 196-197) claim that all performance review systems have issues with meaningfulness, objectivity, accuracy, validity and equity. In our research, most expatriates were evaluated by their line managers while on assignment, i.e. usually not by the people 
who were instrumental in selecting them for IA. While this may in itself have reduced some bias, the lack of objectivity in each appraisal situation may have had positive or negative effects.

More pertinent, the international mobility literature suggests that issues such as culture shock, cross-cultural adjustment and reverse culture shock may adversely impact the performance of expatriates and repatriates (Black et al. 1999; Dickmann and Baruch 2011). In contrast, our findings indicate that the overall performance ratings of both groups are positive which counters some of the arguments on culture shock. We speculate that this finding might be because although cognitive confidence drops due to the 'roller-coaster' of emotions while working abroad (and returning) the individual's ability to cope improves throughout the experience (Haslberger 2008) which may be rated as improved performance by their superiors. Given the many difficulties associated with performance evaluations, superiors may, of course, be biased and give too much goodwill to expatriates struggling in an unfamiliar environment. However, this issue was not explored in depth in this study and while our data raises questions with respect to the 'culture shock' - performance link, we can only urge others to explore these more thoroughly.

Overall, these issues are important as performance is a key index which organizations can use to assess the ROI of IAs. A further indicator of the longer-term pay-off of an international assignment is the subsequent promotion of the repatriate as discussed below.

\section{Promotion}

The level of expatriate experience at the main board or similar level was on average $24 \%$ while $25 \%$ of senior managers had expatriate experience. The analysis of data on 
promotion both during and after expatriation showed that around $10 \%$ of expatriates were promoted while on assignment, and almost 1 in $4(23.7 \%)$ expatriates were promoted during or shortly after return. This number rose to $40 \%$ in the approximately two and a half years subsequent to repatriation. HR experts in participating firms provided promotion rates for comparable peers without expatriate experience which varied between 10 and 15\%. Post-assignment, average promotion rates over the first 1-2 years on return were initially higher for repatriates in their next job, either at their home location or on another IA, than for non-expatriated peers.

While early return was once associated with expatriate failure, Harzing (1995) challenged this assumption. In our study, in the reporting period, four percent of all expatriates returned early from their assignment. Out of these, $1.5 \%$ returned voluntarily (they initiated the move back) while $2.6 \%$ were asked by their companies to leave the assignment. In the interviews with the HR professionals only a small minority of premature returns were seen as expatriation failure. At least half of those who returned voluntarily did so because they saw a good career opportunity for themselves. Moreover, those who were asked to leave by their companies were generally asked to move to fill a vacancy that had come up at home or abroad performance problems were evident only in a small proportion of those. Given that the propensity to be promoted upon early return was slightly higher than that of staff who returned at the prescribed point in time our data throws doubt on early return being a blanket indicator of expatriate failure.

These figures suggest that an international assignment can have a potentially positive effect in terms of career advancement certainly in the short to medium term. For organizations using a talent development strategy which includes a population of internationally experienced individuals, the internal promotion of these individuals 
and their improving performance over time are key to maintaining talent flow within the company.

\section{Repatriation and Retention}

Few of the participating organizations held specific retention statistics geared to global mobility and the action research approach helped them to capture these data and to set up systems to track expatriate and repatriate retention. Turnover rates in the first reporting period after return for repatriates were reported at on average $15 \%$ while the normal managerial labour turnover in the case companies was $7 \%$. Seven of our nine case companies indicated that their repatriate churn was higher than for nonexpatriate peers. Twice as many repatriates leave as those who have never been on an international assignment and companies with the lowest rates of career progression, experienced the highest rates of voluntary turnover among repatriates. Where turnover among repatriates was higher, company representatives identified inadequate career planning as a primary reason. However, for those repatriates who stayed with their employers, labour turnover in the second and third years after return was very low (see Table 2).

Previous studies have indicated that between $10-25 \%$ expatriates leave either during or shortly after their international assignments (Black et al. 1999). Longerterm, between a quarter and a third of repatriates leave their firms within two years of returning (Suutari and Brewster 2003; GMAC 2006). This may be foreseeable given that there is a trend for few repatriates to be guaranteed a "right" of passage home from an IA as reported by Dickmann, Doherty and Mills (2005). In their study, most are offered a lateral move, while a third gain promotion and a few are demoted on return from an IA. Turnover risks were due to repatriates having more marketable 
skills, lack of recognition by their employer of the skills acquired on assignment or reduced responsibility or status on return. Thus, the IA experience can bring benefits to the individual but not necessarily immediately on return or within the sending organization.

In our study, initial levels of attrition and the potential exit of repatriates give cause for concern, certainly for organisations where a key imperative for the use of international assignments is the development of a pool of global talent for the future. For those who stay and survive their 'career wobble' (Doherty and Dickmann 2009) labour turnover is not a critical issue anymore. The use of IA to achieve this is a key challenge for HRM. Like that of Doherty, Brewster, Suutari and Dickmann (2008), the current study presents empirical evidence to suggest that where organisations have focused plans and seek to place employees using their acquired skills they have higher degrees of retention and post-assignment promotions. This is an enduring issue in the repatriation phase of IA.

\section{Actionable knowledge on ROI for IA}

The key insights from this study were synthesised to provide actionable outcomes for participating companies. We constructed case studies on each of the nine organisations providing the specific data details of each company in comparison with average data across participating organizations in the study. While there is the obvious limitation that the companies operate in a range of industries and are faced by diverse contexts (see Table 2), the case material provided the impetus for further exploration, development of useful data indices and managerial actions within individual firms. For instance, three fast-moving consumer goods (FMCG) organisations participated in the study. The overall sample had a mean assignment 
length of 28 months. The FMCG company with the highest 'expatriate premium' among the sample also had the longest average assignment duration (48 months). This was the only company that had not specified definite assignment end dates but relied instead on the end of the assignment being determined by the fulfilment of assignment objectives. The firm introduced expatriation return dates of (normally) three years.

Another firm identified that it had the highest repatriation labour turnover in the sample $(40 \%)$. In response, a longer-term career planning process was implemented. This included a sponsor structure where pre-return conversations with sponsors were designed to manage expectations and to help repatriates find a job. In another company it was noted that while internal documentation had a stated aim to have $80 \%$ developmental assignments, it fell dramatically short of this goal (with only $33 \%$ developmental assignments). This company had a relatively high repatriate turnover rate which was detrimental to its goal of leadership development. These data served as an impetus to review assignment selection which was heavily geared to performance with less focus on the role of individual potential in expatriation.

This study indicates that it is possible for corporate executives to construct an evidence-based business case for expatriation by attributing a value to performance improvement, higher retention of staff and promotions and contrasting these with investment data. However, this does not seem to happen across organizations in a rational and consistent manner, supporting the contention that it is often perceived as a cost of doing business (McNulty et al. 2009). Rather, the case corporations in the current study have used the metrics-based insights to identify areas of perceived weakness and have worked on developing initiatives to address these. This approach links to emerging work which indicates that individuals and organisations monitor their global work circumstances and the 'deal' that they strike with each other. Both 
stakeholders work to remain attractive to internal and external audiences and to reap the benefits of international assignments but there can be significant divergence in motives and outcomes (Dickmann and Doherty 2010).

The results of the project were reviewed relevant to the extant literature on ROI. Although the rationale for the development of global talent has become more clearly articulated, the application and impact of HRM policies and practices are less well illustrated in the literature. The need to shift the focus back to the individual expatriate has been stated (Welch 2003) as it has become increasingly important to integrate career management with both strategic planning and individual career aspirations (Yan, Zhu and Hall 2002). Our data on ROI expands on these insights from an organizational perspective and allows a more sophisticated strategic planning of international assignments. Given the clear link to global careers (Stahl, Miller and Tung 2002; Lazarova and Cerdin, 2007) the data on promotion enables organizations and individuals to factor in key elements of the expatriation deal. The attractiveness of career and development prospects is highly pertinent to an individual's decisions to go abroad (Dickmann et al. 2008). Developments in the performance and retention of expatriates over time can provide important information for organizations in the design of their HR policies and practices. For instance, our data indicate that the management of the return of international assignees during the first year is key to retention. If repatriates survive the 'career wobble' they are highly likely to stay in the organization for the next two years. Thus the importance of purpose of the assignment, perspective taken on the event (i.e. organizational or individual) and time (the temporal patterns of IA outcomes) are key foci for future research on ROI in IA.

\section{Contributions of the approach}


The research approach adopted in this study is time and resource intensive. However participating organizational representatives were engaged through consultation which built mutual objectives and a shared aim for data collection to provide meaningful ROI data. Organizational representatives also highly valued the joint, collaborative effort involved in designing and delivering workable metrics. The process clearly provides valuable insights to participating firms through engagement with academic and consultant experts in the field. During the process of developing the metrics organizational representatives were afforded the opportunity to debate the purpose of metrics and influence the type of measures produced. The measures ultimately developed were valuable, meaningful and useful to participants, evidenced in their use of the subsequent data to implement both internal reviews and benchmarking across organizations. These strategies helped to circumvent the problems of buy-in and the lack of a skills base to develop measures, highlighted in previous research. Further work to assess the reliability and validity of the metrics developed in this project is essential.

Due to the time limits of the project and the in-depth resource intensive nature of the research, the sample of organizations participating in the study was small, limiting the extent to which the findings may reflect general patterns. The companies did span a range of industry sectors and levels of maturity in their use and experience of managing international assignments and therefore provide a baseline data set on which to build future research for comparative and benchmarking purposes and in particular to track trends over time. Tracking individual outcomes in terms of longerterm career outcomes was not possible within the time frame of the research. However, some hard data from the organizational perspective gives a somewhat more optimistic picture than the use of attrition rates. The reporting period may usefully be 
extended to a longer time horizon in future work, in tandem with qualitative input from repatriates themselves to enable these issues to be explored more fully in a longitudinal approach.

\section{Rigour and relevance in $\mathrm{ROI}$ research}

The topic of ROI in IA is an academically and practically challenging task that is crucial in the global context. Assessing ROI faces the dual challenges of designing measures which can begin to expose causal linkages and which meet the demands of practitioner relevance and scholarly rigour. This study is an initial attempt at addressing these complexities within the international human resource management field in an innovative approach to the topic. By using an action research approach which is geared towards the mutual interaction of academics and practitioners in the development of actionable knowledge, the current work takes a first step towards closing the rigour-relevance gap in the field of ROI for IA by giving equal priority to both through an integrated project (Sexton and Lu 2009).

Much of the cost data quoted in the literature seems to rely on estimates and/or describes spans or extremes such as claims that expatriate costs can be 10 times as high as normal salaries. We believe that by actually measuring expatriate investment starting from the company systems and calculating the costs for each of the international assignees we have provided higher quality data. The metrics developed can also be regarded as useful as they have been incorporated in our case companies' systems and have led to corporate policy changes. We hope that in these companies the discourse about 'investment in expatriation' has moved beyond the normal cost assessment to a more holistic exploration of costs and benefits, using diverse temporal and stakeholder perspectives (cf. Dickmann and Doherty 2010). Our collaborative 
approach has many benefits in generating actionable insights but has meant that the corporate centre had an influence in the design of the metrics. In an ideal world it would be more factors and more stakeholders - including the host organization and its local employees, governments and wider society, individuals and their families - that should be taken into account for a sophisticated assessment of expatriate ROI.

\section{References}

Ando, N. (2011), 'Isomorphism and Foreign Subsidiary Staffing Policies', CrossCultural Management: An International Journal, 18, 2, 131-143.

Beardwell, J., and Claydon, T. (2007), Human Resource Management, $\left(5^{\text {th }} \mathrm{ed}.\right)$, London: FT Prentice Hall.

Black, J.S., Gregersen, H.B., Mendenhall, M.E. and Stroh, L. (1999), Globalizing People Through International Assignments, London: Addison Wesley.

Bonache, J., and Brewster, C. (2001), 'Knowledge Transfer and the Management of Expatriation', Thunderbird International Business Review, 43, 1, 145-116.

Bonache, J., and Zárraga-Oberty, C. (2008), 'Determinants of the Success of International Assignees as Knowledge Transferors: A Theoretical Framework', International Journal of Human Resource Management, 19, 1, 118.

Bonache, J., Brewster, C., and Suutari, V. (2001), 'Expatriation: A Developing Research Agenda', Thunderbird International Business Review, 43, 1, 3-20.

Brookfield GMAC (2010), Global Relocation Trends:2010 Survey Report, London: GMAC.

Cappellen, T., and Janssens, M. (2005), 'Career Paths of Global Managers: Towards Future Research', Journal of World Business, 40, 4, 348-360.

Carr, W., and Kemmis, S. (1986), Becoming Critical: Education, Knowledge and Action Research, Basingstoke: Falmer Press.

Cedant Mobility (2002), 2002 Worldwide Benchmark Study: New Approaches to Global Mobility www.cedantmobility.com

Cole, N., and McNulty, Y. (2011), 'Why Do Female Expatriates "Fit-in" Better Than Males?', Cross-Cultural Management: An International Journal, 18, 2, 144164.

Collings, D.G., Scullion, H., and Morley, M.J. (2007), 'Changing Patterns of Global Staffing in the Multinational Enterprise: Challenges to the Conventional Expatriate Assignment and Emerging Alternatives', Journal of World Business, 42, 198-213.

Collings, D.G., Doherty, N., Luethy, M., and Osborne, D. (2011), 'Understanding and Supporting the Career Implications of International Assignments', Journal of Vocational Behavior, doi:10.1016/j.jvb.2011.03.010

Dickmann, M., and Baruch, Y. (2011), Global Careers, London: Routledge.

Dickmann, M., and Debner, C. (2011), 'International Mobility at Work: Companies' Structural, Remuneration and Risk Considerations', in M. Dickmann and Y. Baruch, Global Careers, London: Routledge, pp. 268-292. 
Dickmann, M., and Doherty, N. (2010), 'Exploring Organisational and Individual Career Goals, Interactions and Outcomes of International Assignments', Thunderbird International Review, 52, 4, 313-324.

Dickmann, M., Doherty, N., and Mills, T. (2005), 'Understanding Mobility Influence Factors in the Decision to Accept an International Assignment, Repatriation Issues and Long-term Career Considerations', Report for PricewaterhouseCoopers, Cranfield University School of Management.

Dickmann, M., Doherty, N., and Johnson, A. (2006), 'Measuring the Value of International Assignments', Report for PwC UK Geodesy, Cranfield School of Management.

Dickmann, M., Doherty, N., Mills, T., and Brewster, C. (2008), 'Why Do They Go? Individual and Corporate Perspectives on the Factors Influencing the Decision to Accept an International Assignment', International Journal of Human Resource Management, 9, 4, 731-751.

Doherty, N., and Dickmann, M. (2007), 'Managing the Career Wobble of Repatriates', Developing HR Strategy, July 13.

Doherty, N., and Dickmann, M. (2009), 'Exploring the Symbolic Capital of International Assignments', International Journal of Human Resource Management, 20, 2, 301-320.

Doherty, N., Brewster, C., Suutari, V., and Dickmann, M. (2008), 'Repatriation: The End or the Middle?', in International Human Resource Management: A European Perspective, eds. M. Dickmann, C. Brewster, and P. Sparrow, London: Routledge, pp. 174-191.

Dowling, P., Festing, M., and Engle, A. (2008), International Human Resource Management: Managing People in a Multinational Context, $\left(5^{\text {th }}\right.$ ed.), London: Thomson Learning.

ECA (2010), Managing Mobility Survey, London: Employment Conditions Abroad.

Edström, A. and Galbraith, J.R. (1977), 'Transfer of Managers as a Coordination and Control Strategy in Multinational Organizations', Administrative Science Quarterly, 22, 2, 248-263.

GMAC (2006), http://www.gmacglobalrelocation.com

GMAC (2008), Global Relocation Trends Survey, Woodridge, IL: GMAC Global Relocation Services.

Hailey, J., and Harry, W. (2008), 'Localization: A Strategic Response to Globalization', in International Human Resource Management: A European Perspective, eds. M. Dickmann, C. Brewster, and P. Sparrow, London: Routledge, pp. 19-38.

Harris, H., Brewster, C., and Sparrow, P. (2003), International Human Resource Management, London: CIPD.

Harrison, M.A., and Shaffer, M.A. (2005), 'Mapping the Criterion Space for Expatriate Success: Task and Relationship Based Performance, Effort and Adaptation', International Journal of Human Resource Management, 16, 8, 1454-1474.

Harzing, A.W. (1995), 'The Persistent Myth of High Expatriate Failure Rates', International Journal of Human Resource Management, 6, 2, 457-474.

Haslberger, A. (2005), 'Facets and Dimensions of Cross-cultural Adaptation Refining the Tools', Personnel Review, 34, 2, 85-110.

Haslberger, A. (2008), 'Expatriate Adjustment: A More Nuanced View', in International Human Resource Management: A European Perspective, eds. M. Dickmann, C. Brewster and P. Sparrow, London: Routledge, pp. 130-149. 
Hippler, T. (2009), 'Why Do They Go? Empirical Evidence of Employees' Motives for Seeking or Accepting Relocation', International Journal of International Human Resource Management, 20, 6, 1381-1401.

Hocking, J., Brown, M., and Harzing, A.-W. (2004), 'A Knowledge Transfer Perspective of Strategic Assignment Purposes and Their Path-dependent Outcomes', The International Journal of Human Resource Management, 15, 3, 565-586.

Hodgkinson, G.P., and Rousseau, D.M. (2009), 'Bridging the Rigour-Relevance Gap in Management Research: It's Already Happening!', Journal of Management Studies, 46, 3), 534-546.

Inkson, K., and Arthur, M. (2001), 'How to be a Successful Career Capitalist', Organizational Dynamics, 30, 1, 48-60.

Inkson, K. and Clark, D. (2010), 'Careers and HRM: A Resource Based View', Paper presented at ANZAM, Adelaide, 8-10, December.

Kraimer, M.L., Shaffer, M.A., and Bolino, M.C. (2009), 'The Influence of Expatriate and Repatriate Experiences on Career Advancement and Repatriate retention', Human Resource Management, 48, 1, 27-47.

Kittler, M., Rygl, D., Mackinnon, A., and Wiedemann, K. (2011), 'Work Role and Work Adjustment in Emerging Markets', Cross-Cultural Management: An International Journal, 18, 2, 165-184.

Lazarova, M.B., and Cerdin, J.L. (2007), 'Revisiting Repatriation Concerns: Organizational Support Versus Career and Contextual Influences', Journal of International Business Studies, 38, 404-429.

Lewis, R.E., and Heckman, R.J. (2006), 'Talent Management: A Critical Review', Human Resource Management Review, 16, 139-154

Marchington, M., and Wilkinson, A. (2007), Human Resource Management at Work ( $3^{\text {rd }}$ ed.), London: CIPD.

McCaughey, D., and Bruning, N.S. (2005), 'Enhancing Opportunities for Expatriate Job Satisfaction: HR Strategies for Foreign Assignment Success', Human Resource Planning, 28, 4, 21-29.

McNulty, Y., and Tharenou, P. (2004), 'Expatriate Return on Investment: A Definition and Antecedents', International Studies of Management and Organisation, 34, 3, 68-95.

McNulty, Y., De Cieri, H., and Hutchings, K. (2009), 'Do Global Firms Measure Expatriate Return on Investment? An Empirical Examination of Measures, Barriers and Variables Influencing Global Staffing Practices', International Journal of Human Resource Management, 20, 6, 1309-1326.

Ng, T.W.H., Eby, L., Sorensen, K.L., and Feldman, D.C. (2005), 'Predictors of Objective and Subjective Career Success: A Meta Analysis', Personnel Psychology, 58, 2, 367-408.

ORC Worldwide (2008), Worldwide Survey of International Assignment Policies and Practices, New York: Organizational Resource Councilors Worldwide.

Pfeffer, J., and Sutton, R. (2006), Hard Facts, Dangerous Half-Truths and Total Nonsense: Profiting from Evidence-Based Management, Boston: Harvard Business School Press.

Rousseau, D., and Fried, Y. (2001), 'Location, Location, Location: Contextualizing Organisational Research', Journal of Organisational Behaviour, 22, 1, 1-13.

Sexton, M., and Lu., S.-L. (2009), 'The Challenges of Creating Actionable Knowledge: An Action Research Perspective', Construction Management and Economics, 27, 683-694. 
Sparrow, P. (2006), International Recruitment, Selection and Assessment, London: CIPD.

Sparrow, P., Brewster, C., and Harris, H. (2004), Globalizing Human Resource Management, London: Routledge.

Stahl, G.K., Miller, E., and Tung, R. (2002), 'Towards the Boundaryless Career: a Closer Look at the Expatriate Career Concept and the Perceived Implications of an International Assignment', Journal of World Business, 37, 216-227.

Stahl, G.K, Chua, C.H., Caligiuri, P., Cerdin, J.L., and Taniguchi, M. (2009), 'Predictors of Turnover Intentions in Learning-driven and Demand-driven International Assignments: The role of Repatriate Concerns, Satisfaction with Company Support, and Perceived Careers Advancement Opportunities', Human Resource Management, 48, 1, 89-109.

Stiles, P., and Kulvisaechana, S. (2003), 'Human Capital and Performance: A Literature Review', DTI (Department of Trade and Industry) Accounting for people report. www.accountingforpeople.gov.uk

Strack, R., Caye, J.-M., Thurner, R., and Haen, P. (2009), 'Creating People Advantage in Times of Crisis: How to Address HR Challenges in the Recession', Report for People Management, Düsseldorf, BCG/EAPM, The Boston Consulting Group and the European Association.

Suutari V., and Brewster, C. (2003), 'Repatriation: Empirical Evidence of a Longitudinal Study from Careers and Expectations among Finnish Expatriates', International Journal of Human Resource Management, 14, 7, 1132-1151.

Thomas, D.C., and Lazarova, M.B. (2006), 'Expatriate Adjustment and Performance: A Critical Review', in Handbook of Research on International Human Resource Management, eds. G.K. Stahl and I. Björkman, Cheltenham: Edward Elgar, pp. 247-264.

Tornikoski, C. (2011), 'Fostering Expatriate Affective Commitment: A Total Reward Perspective', Cross-Cultural Management: An International Journal, 18, 2 , 214-235.

Ulrich, D. (1997a), Human Resource Champions: The Next Agenda for Adding Value and Delivering Results, Boston, MA: Harvard University Press.

Ulrich, D. (1997b), 'Measuring Human Resources: An Overview of Practice and Prescription for Results', Human Resource Management, 36, 3, 303-320,

Welch, D.E. (2003), 'Globalization of Staff Movements: Beyond Cultural Adjustment,' Management International Review, 43, 2, 149-169.

Welch, D., Steen, A., and Tahvanainen, M. (2009), 'All pain, little gain? Reframing the value of international assignments', International Journal of Human Resource Management, 20, 6, 1327-1343.

Yan, A., Zhu, G., and Hall, D.T. (2002), 'International assignments for career building: a model of agency relationships and psychological contracts', Academy of Management Review, 27, 3, 373-391. 


\section{Appendix A. Key Metrics ${ }^{1}$}

\section{Expatriate Investment}

$\checkmark$ Costs relating to the expat management costs defined below in 4 .

$\checkmark$ All costs relating to the expat management costs defined below in 4 .

\section{Expatriate Remuneration}

\begin{tabular}{|c|c|c|c|c|c|}
\hline \multicolumn{6}{|c|}{ EXPAT REMUNERATION } \\
\hline \multicolumn{4}{|c|}{ 2a TOTAL COMPENSATION } & & \\
\hline \multirow{2}{*}{$\begin{array}{c}\text { Salaries and } \\
\text { Wages }\end{array}$} & \multicolumn{2}{|c|}{ Variable Compensation } & \multirow{2}{*}{$\begin{array}{c}\text { National } \\
\text { Insurance/ } \\
\text { Social Costs }\end{array}$} & \multirow{2}{*}{$\begin{array}{c}\text { 2b Long- } \\
\text { term } \\
\text { benefits }\end{array}$} & \multirow{2}{*}{$\begin{array}{l}\text { 2c Expat } \\
\text { Allowances }\end{array}$} \\
\hline & $\begin{array}{l}\text { Performance } \\
\text { Related Pay }\end{array}$ & $\begin{array}{l}\text { Attendance } \\
\text { Related Pay }\end{array}$ & & & \\
\hline
\end{tabular}

You should report all Compensation \& Benefits data on a 'gross' basis, i.e. the total cost incurred by the employer during the reporting period. The figures should relate to Current Expats.

\section{2a Total Compensation}

$\checkmark$ Salaries and wages, including geographical supplements or weightings

$\checkmark$ All variable elements of pay as detailed below

$\checkmark$ Premiums and commissions

$\checkmark$ bonuses

$\checkmark$ profit related pay and profit share

$\checkmark$ overtime

$\checkmark$ attendance allowances

$\checkmark \quad$ Other cash incentives

$\checkmark$ Payments for rotating or nonpermanent shifts

× Stock options and other 'long-term'

$\checkmark \quad$ Unsocial hours premiums deferred compensation

Legally required payments to tax/social security authority relating to the employment of people e.g. UK National Insurance and/or host based Social Security Contributions

$x$ Severance payments, compensation for loss of office or other settlements

x Fees for agencies and contractors, outsourced activities and payments to supplementary workers

\footnotetext{
${ }^{1}$ Due to the extent and competitive sensitivity of the measurement information we can only present parts of the measurement approach.
} 


\section{2b Total Compensation}

$\checkmark$ Contributions to home and/or host country pensions and saving plans. If your organization is on a pension holiday you should report the underlying contribution value of payments

$\checkmark$ Health care packages (e.g. medical insurance premiums), long-term disability coverage, accident insurance

$\checkmark$ Life insurance and death benefit contributions

\section{2c Expat Allowances}

$\checkmark$ Company cars/car allowance: include all running costs, lease costs, and depreciation charge incurred, but not purchase prices

$\checkmark$ Mobility allowances, home leave allowances, shipping of personal goods, temporary and long-term storage

$\checkmark$ Rent and/or accommodation allowances

$\checkmark$ Schooling or tuition fees

$\checkmark$ Hardship premiums, location allowances, provision of drivers and/or security

$\checkmark$ Cost of 'look-see' trips prior to assignment

$\checkmark$ Tax equalization costs (i.e. the difference between host country tax cost born by employer less hypothetical tax withheld from employee

3 Many organizations offer a lengthy menu of benefits items, including flexible benefits packages. Our definition details only the most common examples but you should report the cost of all assignment related expenses applicable under your relocation programmes

\section{Expat Management Employees}

$\checkmark$ The number of Employees in the organization that are primarily engaged in the management and administration of international assignments

$x$ Employees that spend less than $50 \%$ of time on expatriate management and/or administration

\section{Expat Management Costs}

Total Compensation \& Benefits costs for Expat Management Exployees (see definition in 3. Above

$\checkmark$ All Expat Outsource Costs (see definition 4a below)

$\checkmark$ Investment in Learning \& Development as outlined in $4 \mathrm{~b}$

$\checkmark$ Internal charges from other business units or functions for support to the Expat Management function

$\checkmark$ Overheads, e.g. facilities, materials, rent, equipment etc and depreciation charges for purchases

a For Total Compensation \& Benefits costs for those involved in the management of Expats capture similar Compensation and Long-term Benefits figures stated in definitions $2 \mathrm{a}$ and $2 \mathrm{~b}$ above

\section{4a Expat Outsource Costs}


$\checkmark \quad$ All fees paid to external parties for Expatriate Management activities, i.e. relocation services, immigration, house search, cultural training, tax services, payroll preparation

x Excludes VAT, sales taxes or other similar value added tax charges applicable to fees paid to third party providers

\section{4b Assignment Related L\&D Investment}

$\checkmark$ Cost of pre-assignment cultural training (either internally resourced or provided externally)

$\checkmark$ Cost of language training

$\checkmark$ All fees paid to external parties for assignment related learning \& development

$x$ Training costs relating to the delivery of technical training activity, e.g. use of overseas systems

x Do not include Expats that have transferred between two or more assignments over the course of the year but who have not returned to their home country 
Table 1. Details of participating organizations

\begin{tabular}{|l|l|l|l|l|}
\hline Company & $\begin{array}{l}\text { Total } \\
\text { Headcount }\end{array}$ & $\begin{array}{l}\text { Expatriate } \\
\text { Number }\end{array}$ & $\begin{array}{l}\text { Female } \\
\text { Expatriates }\end{array}$ & $\begin{array}{l}\text { Data on } \\
\text { Expatriates }\end{array}$ \\
\hline FMCG 1 & $>35,000$ & 305 & 63 & Global \\
\hline Tobacco 1 & $>24,000$ & 100 & 4 & Global \\
\hline $\begin{array}{l}\text { Professional } \\
\text { Services (UK) }\end{array}$ & $>15,000$ & 159 & 41 & UK \\
\hline $\begin{array}{l}\text { Internet } \\
\text { Retailer }\end{array}$ & $>12,000$ & 82 & 21 & Global \\
\hline FMCG 2 & $>155,000$ & 445 & 71 & EMEA \\
\hline Tobacco 2 & $>42,000$ & 1060 & 216 & Global \\
\hline IT & $>6,000$ & 42 & 6 & Global \\
\hline FMCG 3 & $>58,000$ & 208 & 43 & Global \\
\hline Electronics & $>159,000$ & 1049 & 94 & Global \\
\hline
\end{tabular}


Table 2. Expatriate investment, promotion, retention and performance in nine MNCs

\begin{tabular}{|c|c|}
\hline Category & $\begin{array}{c}\text { Mean Data 3,450 } \\
\text { Expatriates }\end{array}$ \\
\hline \multicolumn{2}{|l|}{ Expat Investment } \\
\hline Expatriate Investment per Expat $(£)$ & 171,022 \\
\hline Average Cost per IA $(£)$ & 462,212 \\
\hline Average Expat Comp and Ben $(£)$ & 104,676 \\
\hline Average Expat Allowances (£) & 54,049 \\
\hline Expat Mgmt Costs per Expat (£) & 12,309 \\
\hline Expat Outsource Rate (\%) & 74.8 \\
\hline Expat Cost Premium (\%) & 67.8 \\
\hline \multicolumn{2}{|l|}{ Expat Profile } \\
\hline Talent Pool Expats (\% of all expats) & 16.1 \\
\hline Development Expats (primary goal of assignment) & 18.2 \\
\hline Female Expats (in \% of all expats) & 17.4 \\
\hline \multicolumn{2}{|l|}{ Expat and Repat Performance } \\
\hline Improved Expat Performance (in \% of expats on IA) & 28.4 \\
\hline Lower Expat Performance (in \% of expats on IA) & 15.3 \\
\hline Improved Repat Performance ( $1^{\text {st }}$ reporting period, in $\%$ of returners) & 20.8 \\
\hline Lower Repat Performance ( $1^{\text {st }}$ reporting period, in \%) & 14.8 \\
\hline Improved Repat Performance ( $2^{\text {nd }}$ reporting period, in $\%$ ) & 22.8 \\
\hline Lower Repat Performance ( $2^{\text {nd }}$ reporting period, in \%) & 15.6 \\
\hline Improved Repat Performance (3 $3^{\text {rd }}$ reporting period, in \%) & 24.9 \\
\hline Lower Repat Performance (3 ${ }^{\text {rd }}$ reporting period, in \%) & 13.1 \\
\hline \multicolumn{2}{|l|}{ Internal Promotions } \\
\hline Repat promotions (at time of $1^{\text {st }}$ reporting period) & 23.7 \\
\hline Repat promotions (cumulative, at time of $2^{\text {nd }}$ reporting period) & 36.3 \\
\hline Repat promotions (cumulative, at time of $3^{\text {rd }}$ reporting period) & 39.9 \\
\hline \multicolumn{2}{|l|}{ Retention - Early Terminations during IA } \\
\hline IA Early Termination Rate (\%) & 4.1 \\
\hline Voluntary Early Termination Rate (\%) & 1.5 \\
\hline Involuntary Early Termination Rate (\%) & 2.62 .6 \\
\hline \multicolumn{2}{|l|}{ Retention - Terminations after IA } \\
\hline Terminations in $1^{\text {st }}$ reporting period, in $\%$ & \\
\hline Terminations in $2^{\text {nd }}$ reporting period, in $\%$ & \\
\hline Terminations in $3^{\text {rd }}$ reporting period, in $\%$ & \\
\hline
\end{tabular}


